\title{
Humanistic Philosophy of Tagore
}

\section{Arup Jyoti Sarma}

\begin{abstract}
Tagore's humanism is mainly expressed through his concept of inter-personal ( $I$ and thou) relationship. I shall discuss here Tagore's humanism vis-à-vis inter-personal relationship. In order to expound this idea, I shall embark on his concept of man; man the finite and man the infinite, man within bounds and man the boundless. Tagore has reflected comprehensively and intensely on the ontological status of man in idiosyncratic dimensions and the revelation of the meaning in relation (a) to nature and (b) to modes of inter-personal relationship. I have also discussed the role of language in understanding inter-personal relationship, and finally arrive at the conclusion that the inter-personal relationship of $I$ and thou takes the form of intra-personal relationship of $I$ am thou.
\end{abstract}

Keywords: Tagore, freedom, personality, language

\section{Introduction}

$\mathrm{R}$ abindranath Tagore (1861-1941), the Indian poet and the artist is not a philosopher in the academic sense of the term-in the sense in which one reads and writes on philosophy as an academic discipline. Moreover, he is neither an analyst nor a system builder. Instead he has always considered himself to be a poet and neither a scholar nor a philosopher. ${ }^{1}$ He acknowledges that his religion is a poet's religion. In the Times Literary Supplement the following is written: "Perhaps no living poet was more religious and no man of religion was more poetical than this great Indian."

But Tagore has a vision of the world. The mysteries of man, of nature and of the vast universe have unfolded themselves before his vision and the truth he has realized from the bottom of this comprehension. And this gives us the ground

${ }^{1}$ Rabindranath Tagore, The Religion of Man, in The English Writings of Rabindranath Tagore, Vol.3, ed. by Sisir Kumar Das (New Delhi: Sahitya Akademi, 2008), 120.

${ }^{2}$ Quoted from S. Radhakrishnan, "Most Dear to All the Muses," in Rabindranath Tagore: A Centenary Volume (1861-1961) (New Delhi: Sahitya Akademi, 2010), xviii-xix.

(C) 2012 Arup Jyoti Sarma http://www.kritike.org/journal/issue 11/sarma june2012.pdf ISSN 1908-7330 
to claim Tagore a philosopher. Radhakrishnan aptly remarks that, "In interpreting the philosophy and message of Sir Rabindranath Tagore, we are interpreting the Indian ideal of philosophy, religion, and art, of which his work is the outcome and expression." ${ }^{3}$ Moreover, Tagore's way of thinking is akin to some of the views of western philosophers like Kant, Hegel and Sartre. I shall show their affinity in the course of developing this paper.

In this paper, I shall discuss the humanistic philosophy of Tagore, which is largely expressed through the concept of inter-personal relationship. In order to expound his idea of humanism corresponding to inter-personal relationship, I shall delve more on his concept of man. His views about man/personality can be found in various writings, particularly in Sādhanā (1913), Personality (1917), Creative Unity (1922) and The Religion of Man (1930).

Tagore has reflected comprehensively and intensely on the ontological status of man in idiosyncratic dimensions and the revelation of the meaning in relation (a) to nature and (b) to modes of inter-personal relationships. I shall deal with them extensively on separate sections below.

\section{Man's Relationship with Nature}

Tagore's concept of man/human personality is finding its fruition through the realization of the feeling of intimacy with nature. From his childhood days, he is fascinated by the splendour of nature-the rising of the sun, the chirping of the birds and the whistling of the wind through the trees. He is of the opinion that nature does not lose herself but reveals its true colour to a person's self, having its own eternal bindings with human nature. Nature is not alien but is essentially related to man. In the vastness of nature, we are not unknown strangers; we are her kith and kin. He also compares the beautiful nature with our mother. Tagore writes:

When in the morning I looked upon the light I felt in a moment that I was no stranger in this world, that the inscrutable without name and form had taken me in its arms in the form of my own mother. ${ }^{4}$

Tagore thinks that there are essentially two senses in which we can think of our relationship with nature- one in which we ordinarily treat it as an insentient, objective mode for information, binding down man to the physical and essential needs; and the other in which it satisfies our personality with manifestations that

\footnotetext{
${ }^{3}$ S. Radhakrishnan, The Philosophy of Rabindranath Tagore (London: Macmillan and Co. 1919), preface vii.

${ }^{4}$ Rabindranath Tagore, Gitānjali (Kolkata: UBSPD, 2011), 95.

(C) 2012 Arup Jyoti Sarma http://www.kritike.org/journal/issue_11/sarma_june2012.pdf ISSN 1908-7330 
make our life rich and stimulate our imagination in their harmony of forms, colours, sounds and movements. He argues that we are face to face with this world and our relations to it are manifold. We are always making things that will satisfy our need, and we come in touch with Nature in our efforts to meet these needs. ${ }^{5}$

S.C. Sengupta in his article, "The Surplus in Man: The Poet's Philosophy of Man," argues that the inter-relation between man and nature can be found at the lower or the communication stage and the higher or the communion stage. They are not two different stages. Rather, one stage is ultimately passing over to the growth of another stage. Man has a very good communication with nature. Nature helps man to develop his personality in as much as man helps nature to reveal its beauty. Man grows along with nature in so far as he can identify himself with nature and makes it his messenger of communication. With the help of nature man creates his own nature, creates beauty, and creates art. In his creativity and self-expression, man becomes conscious of the abundance, his ability to go beyond his physical finitude and through creation of art, strives to send his communication to the Supreme Person who reveals Himself to him.

Again, Communication as a form of inter-relation between man and nature has two levels-one is the cognitive and the other is the existential. ${ }^{7}$ At the cognitive level, nature contributes to knowledge not as an externality but as revealed to man. Tagore writes, "All our knowledge of things is knowing them in their relation to the Universe, in that relation which is truth." But man due to his engagements with the day today activities, forgets that nature is his. It is not because that the nature has grown out of touch with us, rather, we do not perceive nature in its aspect of unity; we are driven to destruction by our focus on the fragmentary. He laments that, "we grow out of touch with this great truth, we forget to accept its invitation and its hospitality, when in quest of external success our works become unspiritual and unexpressive." Tagore also quotes here Wordsworth's line:

The world is too much with us; late and soon, Getting and spending, we lay waste our powers.

Little we see in Nature that is ours. ${ }^{10}$

\footnotetext{
${ }^{5}$ Rabindranath Tagore, Personality, in The English Writings of Rabindranath Tagore, vol. 2, ed. by Sisir Kumar Das (New Delhi: Sahitya Akademi, 2008), 349.

${ }^{6}$ S.C. Sengupta, "The Surplus in Man: The Poet's Philosophy of Man," in Rabindranath Tagore and the Challenges of Today, ed. by Bhudeb Chaudhuri and K.G. Subramanyan (Shimla: Indian Institute of Advanced Study, 1988), 39-54.

${ }^{7}$ Ibid., 49.

${ }^{8}$ Rabindranath Tagore, Creative Unity, in The English Writings of Rabindranath Tagore, Vol. 2, ed. by Sisir Kumar Das (New Delhi: Sahitya Akademi, 2008), 496.

${ }^{9}$ Ibid.

${ }^{10} \mathrm{Ibid}$.
} 
At the existential level, we see nature's contribution to human development; and this is possible if one can free oneself from the attitude of closed-ness caused by the ego. There is always a correlation between the extent of receiving from the nature and separating from the ego. There is now a deepening of self-knowledge, and self-development at the higher level of relatedness to nature is communion or unity. Tagore thinks that the unity of man and nature has its source in the One or the Absolute. The spirit and nature are the twin aspects of the Absolute.

It is in man's consciousness of a deeper unity with nature, with the universe, and finally with the Supreme Person who has created this universe for man. Communion as a higher mode of relationship between man and nature is characterised by inwardness and depth. The depth has an educating purpose. Nature teaches man in as much as we teach others. The communion as a matter under discussion is the experience of joy, freedom and love. Tagore comments:

When a man does not realize his kinship with the world, he lives in a prison-house whose walls are alien to him. When he meets the eternal spirit in all objects, then is he emancipated for then he discovers the fullest significance of the world into which he is born; then he finds himself in perfect truth, and his harmony with the all is established. ${ }^{11}$

Therefore, in Tagore's opinion nature forms the background for the development of human personality. Man and nature have a relation of collaboration and transcendence. It is not a relation of anti-thesis between man and nature-man against nature, but a relation of man with nature. Both man and nature are, ontologically, equally important for Tagore. ${ }^{12}$

But man is not satisfied with what he is. He has a desire to transcend his own limitation and finitude and ultimately wants to reach a point where one is identical with oneself $(\mathrm{I}=\mathrm{I})$, and it is nature that helps man to realize this goal. Man carries within himself the beauty of nature and an urge to transcend one's facticity and reaches the Infinite. Tagore says that man is a bridge between two poles. He remarks:

At one pole of my being I am one with stock and stones.

There I have to acknowledge the rule of universal law. That is where the foundation of my existence lies, deep down

\footnotetext{
${ }^{11}$ Rabindranath Tagore, Sādhanā, in The English Writings of Rabindranath Tagore, vol. 2 283.

${ }^{12}$ S.P. Banerjee, "Rabindranath's Concept of Personality," in Rabindranath Tagore and the Challenges of Today, 31.

(C) 2012 Arup Jyoti Sarma http://www.kritike.org/journal/issue 11/sarma june2012.pdf ISSN 1908-7330 


\section{HUMANISTIC PHILOSOPHY OF TAGORE}

below....But at the other pole of my being I am separate from all. There I have broken through the cordon of equality and stand alone as an individual. I am absolutely unique, I am I, I am incomparable. ${ }^{13}$

But Tagore asserts that realizing the Absolute/Infinite requires more toil and suffering. Tagore says in Gitānjali:

Obstinate are the trammels, but my heart aches

when I try to break them.

Freedom is all I want, but

to hope for it I feel ashamed.

I am certain that priceless wealth is in thee,

and that thou art my best friend, but I have not

the heart to sweep away the tinsel that fills my room.

The shroud that covers me is

a shroud of dust and death;

I hate it, yet hug it in love. ${ }^{14}$

Tagore's notion of the consciousness of consciousness (I=I) has affinity with the transcendental consciousness of Immanuel Kant. Kant says that all representations have relations to empirical consciousness and all empirical consciousness has a necessary relation with transcendental consciousness. It is necessary in our knowledge situation that all empirical consciousness belong to one transcendental consciousness, that is, the consciousness of 'I' or me. Kant argues, "... all empirical consciousness has a necessary consciousness of myself as original apperception. It is therefore absolutely necessary that in my knowledge all consciousness should belong to a single consciousness, that of myself."15 This abiding and unchanging ' $I$ ' (pure apperception) is the basis of all our representations. This pure apperception is the highest principle in the whole sphere of human knowledge. This consciousness of 'I' or the thinking 'I' expresses the act of determining my existence. I am conscious of my own existence. This consciousness of my existence is given by self-intuition.

According to Tagore, man's personality and creativity go together. Man comes out of his boundary of physical necessities and moves forward to realize the Infinite run on two parallel lines-that of utility and of self-expression. True

\footnotetext{
${ }^{13}$ Tagore, Sādhanā, 306.

${ }^{14}$ Tagore, Gitānjali, 28.

${ }^{15}$ Immanuel Kant, Critique of Pure Reason, trans. by N.K. Smith (London: Macmillan Press, 1973), 142.

(C) 2012 Arup Jyoti Sarma http://www.kritike.org/journal/issue 11/sarma june2012.pdf ISSN 1908-7330 
freedom is the transcendence of mere being through creative becoming. This reminds us of the opinion of Sartre, when he says:

Man is all the time outside of himself: it is in projecting and losing himself beyond himself that he makes man to exist; and, on the other hand, it is by pursuing transcendent aims that he himself is able to exist. Since man is thus selfsurpassing, and can grasp objects only in relation to his selfsurpassing, he is himself the heart and centre of his transcendence. There is no other universe except the human universe, the universe of human subjectivity. ${ }^{16}$

The creation of art, music, painting and dance elevates man from a mere being to a personal man. The personality of man, according to Tagore, is "conscious of its inexhaustible abundance; it has the paradox in it that it is more than itself; it is more than as it is seen, as it is known, as it is used. And this consciousness of the infinite, in the personal man, ever strives to make its expressions immortal and to make the whole world its own. ${ }^{17}$ Sartrean notion of ' $m a n$ is not what he is, man is what he is not' echoes in the writings of Tagore, when he says, "...man has a feeling that he is truly represented in something which exceeds himself. He is aware that he is not imperfect, but incomplete." ${ }^{18}$

The personal man, according to Tagore, is the highest in man, the Eternal man, the Complete Man in this realization of the unity of beauty, truth and goodness. There is an inter-relation between the world in which we live and the personality of man. In fact, this world is indispensable for the development of the personality of man. In his words, "with our love and hatred, pleasure and pain, fear and wonder, continually working upon it, this world becomes a part of our personality....If this world were taken away, our personality would lose all its content." ${ }^{19}$

Tagore calls this creative urge, which is found within all human beings as the surplus in man. This surplus seeks its channel in the creation of the beautiful and the good that builds man's true world; and this creation is the proper function of Art. ${ }^{20}$ In creating Art, man reveals himself and not the object. In his creativity, man realizes the Supreme Person (Jivan Devatä), who has made this world so personal to man. Tagore thinks that man is true, where he feels his Infinity or the

${ }^{16}$ Jean- Paul Sartre, Existentialism and Humanism, trans. by Philip Mairet, (London: Butler and Tanner Ltd., 1948), 55.

${ }^{17}$ Tagore, Personality, 362.

${ }^{18}$ Tagore, The Religion of Man, 106.

${ }^{19}$ Tagore, Personality, 353.

${ }^{20}$ Ibid., 359.

(C) 2012 Arup Jyoti Sarma http://www.kritike.org/journal/issue 11/sarma june2012.pdf ISSN 1908-7330 
Divine; and the Divine is the creator in him. Therefore, with the attainment of his truth, he creates. ${ }^{21}$ In his approaching the Supreme Person, man also gets the assurance of his immortality, for men are the symbol of light. Whenever they fully realize themselves they feel their immortality. ${ }^{22}$ Man can live in his own creation and considers the world of God as his own world. The Supreme Person reveals Himself to us in a world of endless beauty across the lightness world of facts. In this respect, he argues, man listens to the voices, which was once heard by the great Indian sages:

Hearken to me, ye children of The Immortal, dwellers of the heavenly

Worlds, I have known the Supreme Person who comes as light from the dark beyond. ${ }^{23}$

While explaining the distinctiveness of human personality, Tagore also shows the difference between man and other animals. An animal is very nearly bound within the limits of its necessities, the greater part of its activities are being necessary for the self-preservation and the preservation of the race. Man on the other hand, has the capacity to transcend these necessities and exercises his freedom in creativity. According to him, "Man has a fund of emotional energy which is not all occupied with his self-preservation. This surplus seeks its outlet in the creation of Art, for man's civilization is built upon his surplus." ${ }^{24} \mathrm{He}$ further says that man as a knower is not fully himself; but as a person, he is the organic man, who has the inherent power to select things from his surrounding world and makes them his own. ${ }^{25}$

A work of art has its origin in a feeling of unity, which is creative, and therefore a successful work of art is a creative unity. Tagore conceives of art as an encounter of the self with its other. The world and the personal man are face to face, like friends. The central theme of Tagore's theory of art is the notion that art is a bridge across the chasm, which alienates the individual from the world. The art is a process of delineation. The intentionality of human consciousness maps onto a non-solipsistic world are brought out by this statement:

Reality reveals itself in the emotional and imaginative background of our mind. We feel ourselves in a special field of realization. The consciousness of the real within me seeks for its corroboration the touch of the Real outside me. In art

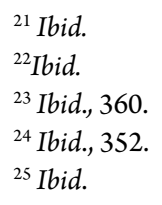


we express the delight of this unity by which the world is realised as humanly significant. Where the harmony is not deeply felt, we are aliens and perpetually homesick. By nature man is an artist; he never receives passively a physical representation of things round him. There goes on a continual adaptation, a transformation of his sentiments and imagination. ${ }^{26}$

Furthermore, there is another important characteristic in man, which the other creatures are lacking. In Tagore's opinion, it is the dualism in man's consciousness of what is and what ought to be. Again, in the animal life, the conflict is between what is and what is desired, but in man, the conflict is between what is desired and what should be desired. Tagore says that, "what is desired dwells in the heart of the natural life, which we share with animals; but what should be desired belongs to a life which is far beyond it." 27

Therefore, the important distinction between what is and what ought to be looms large in the relation between man and other animals. In this relation, there is a continuation and a conflict. Many things that are good for one are evil for another. This necessity of struggle with himself has produced an ingredient to his persona, which is character. From the life of desire, it directs man to the life of purpose, and in Tagore's words, it is the life of the moral world. ${ }^{28}$

In the ethical world, we come from the world of nature into the world of humanity, the world where man has his freedom of creation. The human world is truly a world of ideas and institutions, of stored knowledge and trained habits. This is the world of man's second birth, "the extra-natural world, where the dualism of the animal life and the moral makes us conscious of our personality as man." ${ }^{29}$ It thus, shows a development from the natural order of existence to a spiritual order of existence, that is, to the inter-personal (I-thou) level of existence. With this I come to the next section of my work, i.e., to the mode of inter-personal relationship.

\section{Inter-personal Relationship (I and Thou)}

In this section, I shall show the ontological aspects of the $I$ and Thou relationship in Tagore's humanistic thoughts. The assertion of the primordial relationship is the essence of Tagore's humanism; and he calls his humanism the

${ }^{26}$ Quoted from Pabitra Kumar Roy, Beauty, Art and Man: Recent Indian Theories of Art (Shimla: Indian Institute of Advanced Study, 1990), 1.

${ }^{27}$ Tagore, Personality, 378.

${ }^{28}$ Ibid.

${ }^{29}$ Ibid.

(C) 2012 Arup Jyoti Sarma http://www.kritike.org/journal/issue 11/sarma june2012.pdf ISSN 1908-7330 
Religion of Man. But the term, 'Religion', does not suggest that man is under the control of an infinite spiritual being like God. He clears his opinion about religion in the following words:

To me religion is too concrete a thing, though I have no right to speak about it. But if ever I have somehow come to realize God, or if the vision of God has ever been granted to me, I must have received the vision through this world, through men, through trees and birds and beasts, the dust and the soil. ${ }^{30}$

The function of religion, according to him, then is to bring the individual into harmony in reason, in love, in deed with the Supreme Man, the Universal being. ${ }^{31}$ The reality of the Supreme Person is as much dependent upon the personal being as the latter is dependent upon the former. In this sense, God is also a personal being like man. The Vedantic conception of the divinity in manNara-Närāyana, is developed in Tagore's philosophy of the Religion of Man, avoiding the formal religions with their rituals, superstitions and mythologies. God is there in every life (Jivan Devatā), and the realization of it through knowledge or intuition is the essence of religion. He thinks that God is to be found not in temples or mosques but in humanity itself. Tagore's concept of humanism is basically to the service of mankind. He writes in Gitānjali:

Deliverance is not for me in renunciation.

I feel the embrace of freedom

in a thousand bonds of delight.

Thou ever pourest for me the first draught of

thy wine of various colours and fragrance,

Filling the earthen vessel to the brim.

My world will light its hundred different lamps

with thy flame and place them before

the altar Of thy temple. ${ }^{32}$

According to Tagore, the state of realising our relationship with all through the union with the divine is the ultimate end and fulfilment of humanity. Therefore, the spirit of One in God has the many for the realisation of the unity

\footnotetext{
${ }^{30}$ Quoted from Sarvapalli Radhakrishnan, “Most Dear to All the Muses,” xix.

${ }^{31}$ Quoted from Rabindranath Tagore, "My Memories of Einstein," in The Kenyon Review, New Series, 23: 2 (Spring 2001), 19.

${ }^{32}$ Tagore, Gitānjali, 73.

(C) 2012 Arup Jyoti Sarma http://www.kritike.org/journal/issue 11/sarma june2012.pdf ISSN 1908-7330 
and the truth behind this spiritual union is love. He thinks that man is above all a lover, his freedom and fulfilment is in love, which is another name for perfect comprehension. By this power of comprehension, this permeation of his being, he is united with the all-pervading spirit. Through love, human society is for the best expression of man, and that expression, according to its perfection, leads him to the full realization of the divine in humanity. Tagore says:

In love the sense of difference is obliterated and the human soul fulfils its purpose in perfection, transcending the limits of itself and reaching across the threshold of the infinite. Therefore love is the highest bliss that man can attain to, for through it alone he truly knows that he is more than himself, and that he is at one with the All. ${ }^{33}$

This is the ultimate end of man: to find the One which is in him, which is his truth, which is his soul; the key which opens the gate of the spiritual life, the heavenly kingdom. But that One in us is always seeking for unity-unity in knowledge, unity in love, unity in purpose of will; its highest joy is when it reaches the infinite one within its eternal unity. ${ }^{34}$

Tagore equates love with truth and truth with beauty. He argues that it is only when one can detaches from the narrow boundaries of selfishness, can one have a true vision of the beauty, which is omnipresent and realise its everlasting relation with truth. In his opinion, "this is the ultimate object of our existence, that we must ever know that 'beauty is truth, truth beauty;' we must realise the whole world in love, for loves gives its birth, sustains it, and takes it back to the bosom." 35 Furthermore, Tagore thinks that there is no other concept of truth, except human truth. The entire universe is linked up with us, and it indicates that the truth of the universe is the human truth. According to Tagore, "when our universe is in harmony with Man, the eternal, we know it as truth, we feel it as beauty." 36 Moreover, according to Tagore, truth and beauty are also dependent upon man. He points out, "beauty is in the ideal of perfect harmony which is in the Universal Being; Truth the perfect comprehension of the Universal Mind. We individuals approach it...through our accumulated experience, through our illumined consciousness..." ${ }^{37}$ It is pertinent to discuss here the conversations of Tagore and

${ }^{33}$ Tagore, Sādhanā, 291.

${ }^{34}$ Ibid., 295.

${ }^{35}$ Ibid., 336.

${ }^{36}$ Quoted from "Conversations and Interviews: Einstein and Tagore," in The English Writings of Rabindranath Tagore, vol. 3, ed. by Sisir Kumar Das, (New Delhi: Sahitya Akademi, 2008), 911.

${ }^{37} \mathrm{Ibid} ., 912$.

(C) 2012 Arup Jyoti Sarma http://www.kritike.org/journal/issue 11/sarma june2012.pdf ISSN 1908-7330 
Einstein on the issue of truth and beauty. ${ }^{38}$ Einstein agrees with Tagore that beauty is dependent upon the realisation of man. As he says, "if there would be no human beings anymore, the Apollo of Belvedere would no longer be beautiful." ${ }^{39}$ But truth cannot be dependent upon man. Einstein argues that he cannot prove this scientifically but he has a firm belief that "truth must be conceived as a truth that is valid independent of humanity..."

It should be noted that bondage and liberation are not antagonistic in love. According to Tagore, love is most free and bound at the same time. As he says:

In love at one of its poles you find the personal, and at the other the impersonal. At one you have the positive assertion-Here I am; at the other the equally strong denial - I am not. Without this ego what is love? And again, with only this ego how can love be possible?.... If God is absolutely free, there would be no creation. The infinite being has assumed into him the mystery of finitude. And in him who is love the finite and the infinite are made one. ${ }^{41}$

He however remarks that desiring other man's possession may be a hindrance in realizing love. The longing or the desire is not for one's possessions, the reason being that such possessions do not satisfy the ultimate needs. Longing or the desire belongs actually to the lower self. Renunciation is necessary for the true self or the soul of man. He says, "...this joy of mine is the joy of love which comes of the renouncing of myself in him.." ${ }^{32}$ What is really needed of the human beings is that they should grow step by step, and to realize that the moral and the spiritual side of the soul is more than his possessions. The moral side represents training of unselfishness and the control of desire. The spiritual side represents sympathy and love. ${ }^{43}$

However, it is remarkable that Tagore is not a believer of asceticism or the denouncer of the worldly life. As he says:

No, my friend, I shall never leave my heart and home, and retire into the forest solitude, if rings no merry laughter in its echoing shade and if the end of no saffron mantle flutters in

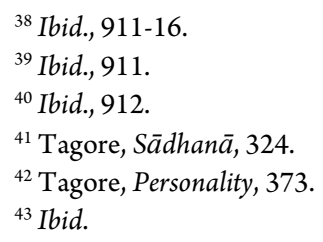


the wind; if it silence is not deepened by soft whispers. I shall never be an ascetic. ${ }^{44}$

He believes in the renunciation of bad desires, those desires which are not good, should be avoided. The moral development lies in man's growth to his unselfish and true self through good and desirable acts. In his moral life, man has the sense of obligation and his freedom at the same time. Morality relates to conduct which essentially is a function of our will. In his opinion, "what the intellect is in the world of Nature our will is in the moral world." ${ }^{45}$ Morality cannot be reduced to mere good conduct. It is a way of attaining to what one ought to be through right or good doing. Morality consists in being good through good action. Such action is possible through discrimination between the desired and the desirable. Selfishness or egoism is normally desired, but it is not desirable because it hinders the proper development of social relationship and the growth of the true self of man.

Tagore believes in the Gitā's concept of freedom; true freedom is not the freedom from action but freedom in action. ${ }^{46} \mathrm{He}$ says that that there may be two types of freedom - outer and inner, where outer freedom is the freedom from the guidance of pleasure and pain, and inner freedom is from the narrowness of selfdesire. ${ }^{47}$ We have our own freedom of will, which can only find its true meaning in relation to the freedom of other wills. The more our will is freed and widened, the stronger our relationship with the universal world of reason. This is the bond of union through which man is related to the world and he feels an exceeding joy through this communion. Tagore writes:

... when intellect is freed from the bondage of interest it discovers the world of universal reason, with which we must be in harmony fully to satisfy our needs; in the same manner when will is freed from its limitations, when it becomes good, that is to say, when its scope is extended to all men and all time, it discerns a world transcending the moral world of humanity. It finds a world where all our disciplines of moral life find their ultimate truth, and our mind is roused to the idea that there is an infinite medium of truth through which goodness finds its meaning. That I become more in my union with others is not a simple fact of

\footnotetext{
${ }^{44}$ Rabindranath Tagore, Gardener, in Tagore online literature, <http://www.onlineliterature.com/tagore-rabindranath/2955/>, 15 August, 2012.

45 Tagore, Personality, 379.

${ }^{46}$ Tagore, Sädhanā, 310.

${ }^{47}$ Tagore, Personality, 379.

(C) 2012 Arup Jyoti Sarma http://www.kritike.org/journal/issue 11/sarma june2012.pdf ISSN 1908-7330 


\begin{abstract}
arithmetic. We have known that when different personalities combine in love, which is the complete union...but it is what was imperfect finding its perfection in truth, and therefore in joy; what was meaningless, when unrelated, finding its full meaning in relationship. ${ }^{48}$
\end{abstract}

It is incredible that Einstein also touches the topic of the 'freedom of will' in a short essay entitled "Free Will,"49 (that represents his contribution to The Golden Book of Tagore, compiled in honour of Tagore's seventieth birthday in 1931). It is Einstein's simple convictions and not demonstrations that there is freedom of will. Einstein writes, “...thou hast served mankind all through a long and fruitful life, spreading everywhere a gentle and free thought..." 50

There is a popular belief that Tagore's idea may be roughly coined as spiritualistic. At least, by going through some of his writings, one may have such a perception. But this will not be a complete interpretation about him. While Tagore's thoughts can be considered spiritual but it is not a mysticism of irrationality. Spiritualism of Tagore is not equivalent to Godliness. His God, wherever there is one, manifests himself in the divinity of man. As Radhakrishnan points out, "to Rabindranath God is not a being seated high up in the heavens, but a spirit immanent in the whole universe of persons and things." ${ }^{\text {"1 }}$ The concept of the all-pervading spirit or the absolute and its realization will not be possible, if the faculty of reason has no control over our mind, which is liable to be stultified by fear, superstition, false prejudices and dogmas.

Tagore says in Gitānjali:

Where the mind is without fear and the head is held high;

Where knowledge is free;

Where the clear stream of reason has not lost its way into the dreary desert sand of dead

habit;

where the mind is led forward by thee into ever-widening thought and action .... ${ }^{52}$

${ }^{48}$ Ibid.

${ }^{49}$ Albert Einstein, "About Free Will," in The Kenyon Review, New Series, 23:2 (Spring 2001), 30-31.

${ }^{50} \mathrm{Ibid} ., 31$.

${ }^{51}$ Radhakrishnan, The Philosophy of Rabindranath Tagore, 54.

${ }^{52}$ Tagore, Gitānjali, 35.

(C) 2012 Arup Jyoti Sarma

http://www.kritike.org/journal/issue 11/sarma june2012.pdf

ISSN 1908-7330 
He further says in Gitānjali:

I shall ever try to keep all untruths out from my thoughts, knowing that thou art that truth which has kindled the light of reason in my mind..$^{53}$

This further brings to mind Kant's position in Religion Within the Limits of Reason Alone, where he says that morality leads ineluctably to religion, and the religion or faith is within the limits of reason. ${ }^{54}$ Kant says, “...reason can be found to be not only compatible with Scripture but also at one with it..." 55 The idea behind this is that there is not a single belief or hope which is not under the ambit of reason, but only that he identifies a range of beliefs or hopes whose structure places them within the limits of reason. ${ }^{56}$

The spiritual bond between the personal man and the universal world of reason ensure our integration in the national sphere and paves the way for international amity. According to him, human civilization can best be understood through our loving concern for mankind. He says that, “...we never can have a true view of man unless we have a love for him. Civilisation must be judged and prized, not by the amount of power it has developed, but by how much it has evolved and given expression to, by its laws and institutions, the love of humanity." ${ }^{57}$ Tagore works for one supreme cause, the union of all sections of humanity in sympathy and understanding, in truth and love. His Visva-Bhärati is a university of his dreams, where the whole world has become a single nest: yātra višvam bhāvati ekānidam. It is one such university, where all cultures, languages and faiths are welcome to form a symphony of universalism.

\section{Concluding Remarks}

In conclusion, I would like to highlight mainly upon the role of language in human ontology, and Tagore's humanism vis-à-vis inter-personal relationship of $I$ and thou that takes the form of intra-personal relationship of $I$ am thou. I shall explain them below-

Language plays an important role in human ontology. Tagore's view of language is ontological, because, human ontology determines the nature and

\section{${ }^{53}$ Ibid., 4.}

${ }^{54}$ Immanuel Kant, Religion Within the Limits of Reason Alone, trans. by Theodore M. Green and Hoyt H. Hudson (Chicago: The Open Court Publishing Company, 1934), preface 4.

${ }^{55}$ Ibid.

${ }^{56}$ Onora O'neill, "Kant on Reason and Religion," in The Tanner Lecture on Human Values, (April 1-3, 1996), 302.

${ }^{57}$ Tagore, Sādhanā, 323.

(C) 2012 Arup Jyoti Sarma http://www.kritike.org/journal/issue_11/sarma june2012.pdf ISSN 1908-7330 
function of language. Man expresses himself through his creativity, and language is one of the important modes of communication of man's self-revealing activity.

Man is an expressive being, and therefore, he is capable of achieving selfclarity and freedom. Freedom is integral to a self-realizing subject. As Charles Taylor says, "The realization of man...involved an expression, in the sense of a clarification, of what he is; and this is why the highest fulfilment comes in expressive activity." ${ }^{58}$

Now, the use of language can definitely help us to understand Tagore's notion of the inter-personal relationship, because he distinguishes between experiences as such, and one's consciousness of experience. He maintains that in art, it is not the experience itself that the artist expresses, but his personality, i.e., his own consciousness of the experience. The telos of art is to project another order of man's being, man's true world. This world, which transcends the world of facts, is called the world of expression, and it is a creation of man's personality. Personality, therefore, according to Tagore, is both the 'I' and 'Thou' of human existence. According to Tagore, self-expression is the important channel of communication. As an expressive being, man recovers communion with the universe. It is in man's consciousness of a deeper unity with nature, with the world, of which we are a part. The self- revealing being (I) is in interchange with the greater nature.

Furthermore, our communion with nature also entails our relation with the 'other'. The self-expressive being carries an eternal relation with the other and the other is also dependent upon my existence. In this way, there arises an interpersonal relationship between 'myself' and the 'other' ( $I$ and thou). It will be appropriate to fit here the views of Hegel that the Idea becomes its other, and then returns into self-consciousness in Geist. The life of the absolute subject is essentially a process, a movement, in which it posits its own conditions of existence to the universe, and then overcomes the opposition of these conditions to realize its goal of self-knowledge. ${ }^{59}$

But at the deeper ontological level, this inter-personal relation of $I$ and thou takes the form of intra-personal level of human existence (I am thou). I am dependent upon other and the other is a condition for my union with the allpervading spirit. Tagore thinks that to attain our world-consciousness, we have to unite our feelings with this all-pervasive infinite feeling, and this is possible when we free ourselves from the bonds of personal desires, prepare ourselves for our social obligations and sharing the burdens of our fellow beings. Thus, $I$ and thou work for a common cause to achieve the unity of consciousness. He says that to be truly united in knowledge, love and service with all beings, and thus to realize

\footnotetext{
${ }^{58}$ Charles Taylor, Hegel (London: Cambridge University Press, 1975), 21.

${ }^{59}$ G.W.F. Hegel, Phenomenology of Spirit, trans. by A.V. Miller (America: Clarendon Press, 1979), preface 14
}

(C) 2012 Arup Jyoti Sarma

http://www.kritike.org/journal/issue 11/sarma june2012.pdf

ISSN 1908-7330 
one's self in the all-pervading God is the essence of goodness, and it is also the key that opens the gate of the spiritual life, the heavenly kingdom, or as Kant would have it: founding of a kingdom of God on Earth.

Department of Philosophy, Tripura University, India

\section{References}

Banerjee, S.P., "Rabindranath's Concept of Personality," in Rabindranath Tagore and the Challenges of Today, ed. by Bhudeb Chaudhuri and K.G. Subramanyan, (Shimla: Indian Institute of Advanced Study, 1988).

Einstein, Albert, "About Free Will," in The Kenyon Review, New Series, 23:2, Cultures of Creativity: The Centennial Celebrations of the Nobel Prizes, (Spring 2001).

Hegel, G.W.F., Phenomenology of Spirit, trans. by A.V. Miller (America: Clarendon Press, 1979).

Kant, Immanuel, Critique of Pure Reason, trans. by N.K. Smith (London: Macmillan Press, 1973). , Religion Within the Limits of Reason Alone, trans. by Theodore M. Green and Hoyt H. Hudson (Chicago: The Open Court Publishing Company, 1934).

O'neill, Onora, "Kant on Reason and Religion," in The Tanner Lecture on Human Values (April 1-3, 1996).

Radhakrishnan, S., The Philosophy of Rabindranath Tagore (London: Macmillan and Co., 1919).

, "Most Dear to All the Muses," in Rabindranath Tagore: A Centenary Volume (1861-1961) (New Delhi: Sahitya Akademi, 2010).

Roy, Pabitra Kumar, Beauty, Art and Man: Recent Indian Theories of Art (Shimla: Indian Institute of Advanced Study, 1990).

Sartre, Jean- Paul, Existentialism and Humanism, trans. by Philip Mairet, (London: Butler and Tanner Ltd., 1948).

Sengupta, S.C., "The Surplus in Man: The Poet's Philosophy of Man," in Rabindranath Tagore and the Challenges of Today, ed. by Bhudeb Chaudhuri and K.G. Subramanyan (Shimla: Indian Institute of Advanced Study, 1988).

Tagore, Rabindranath, Sädhanā, in The English Writings of Rabindranath Tagore, vol. 2, ed. by Sisir Kumar Das (New Delhi: Sahitya Akademi, 2008). , Personality, in The English Writings of Rabindranath Tagore, vol. 2, ed. by Sisir Kumar Das (New Delhi: Sahitya Akademi, 2008). ,Creative Unity, in The English Writings of Rabindranath Tagore, vol. 2, ed. by Sisir Kumar Das (New Delhi: Sahitya Akademi, 2008).

(C) 2012 Arup Jyoti Sarma http://www.kritike.org/journal/issue 11/sarma june2012.pdf ISSN 1908-7330 


\section{HUMANISTIC PHILOSOPHY OF TAGORE}

The Religion of Man, in The English Writings of Rabindranath Tagore, vol.3, ed. by Sisir Kumar Das (New Delhi: Sahitya Akademi, 2008).

, Gitānjali (Kolkata: UBSPD, 2011).

, Gardener, in Tagore online literature, <http://www.onlineliterature.com/tagore-rabindranath/2955/>, 15 August, 2012.

, "My Memories of Einstein," in The Kenyon Review, New Series, 23: 2, Cultures of Creativity: The Centennial Celebrations of the Nobel Prizes, (Spring 2001).

, "Conversations and Interviews: Einstein and Tagore," in The English Writings of Rabindranath Tagore, vol. 3, ed. by Sisir Kumar Das, (New Delhi: Sahitya Akademi, 2008).

Taylor, Charles, Hegel (London: Cambridge University Press, 1975). 